\title{
Issues in Latin America. Sociocultural contrasts and their representations in contemporary literature
}

\author{
Sorina-Crina Ghiață ${ }^{\star}$ \\ Faculty of Letters, "Alexandru Ioan Cuza" University, Bd. Carol I 11, 700506 Iași, Romania
}

\section{Article info}

History:

Received August 8, 2020

Accepted October 3, 2020

Published December 27, 2020

Key words:

literary discourse

multiculturalism

postcolonialism

identity

violence

\begin{abstract}
Starting with the independence process of all the territories once colonies and later, overseas territories of the different states of Western Europe, Latin America meant an association of unique paradoxes. Portugal and Spain have dominated in the past, especially from a linguistic and religious perspective, the current space that becameavaried cultural environment. In this context, the aim of this study is to capture, in the introductory part, characteristics of the Latin American complex identity (reflected, for example, in the names associated with this space of civilization, in political circumstances and social issues, in particular). In addition, another purpose is to highlightthe way in which these aspects are considered in the prose of modern LatinAmericanwriters, Rodrigo Rey Rosa and Héctor Abad Faciolince. At the same time,emphasizing the scourgeof discrimination or inequality, but especially the perpetual violence, thestudyconcludes with a reference (also found in the literary discourse of the two texts chosen for analysis, Los sordos and El olvido que seremos) to the ethical spirit, but also to the feeling of empathy-subjects approached by both writers-in a world that seems more and more fragmented and depersonalized, as if it has been occupied by a continuous stigma of imbalance.
\end{abstract}

\section{Generalities}

When we talk about Latin American literature today, we inevitably refer to authors who, in their works, through the adopted theme, reflect fundamental issues of everyday life in Latin America. In terms of the historical, social, cultural and economic context that defines the southern territory of the New World, Latin America has proven to be, since its birth, so different from other places marked and definitively transformed by civilization, throughout history.

The American continent has been, since its discovery and until now, a part of the world immersed in conquest campaigns, revolts, revolutions, wars, but also dominated by totalitarian political regimes, referring, of course, to countries bordering the United States to the south and the Caribbean. We can say that this territory of the world has not been left out of the crisis situations, nor has it been exempted from the tumult of history that has transformed it into an environment full of contrasts (some political, geographical, others social, more above all, but also culturally).

For many historians, the appreciation of the Latin American space as having a homogeneous structure turns out to be an almost impossible mission, considering the fact that it represents an extremely diverse cumulation of nations, ethnicities and races. However, there are voices that go in favor of the idea that America could not exist outside the concept of unity-Dado que, si dicho principio de unidad no existiera, esta historia no seria posible $[. . .]^{1}$ (Zanatta, 2012, p. 12) - and therefore, in support of this hypothesis, they provide strong arguments. One of them undoubtedly refers to the countless efforts to gain independence.

*Email address: sorina.ghiata@yahoo.com.

1 "Since, if such a principle of unity did not exist, this story would not have been possible" (our transl.). 


\subsection{Denominations associated with the Latin American sociocultural space}

Among the European countries that have exerted a strong linguistic influence on Latin America, Spain certainly ranks first. This is also why, when referring to Spanish-speaking (and also majority-speaking) American states, Hispanics often use several terms, including Hispanoamérica. The denomination Iberoamérica ${ }^{2}$, however, is not used with the same recurrence. In addition to this terminological association that reflects the unitary character of the continent, other clarifications regarding the terms attributed to Southern America also refer to geographical and sociocultural diversity. Among them we mention Sudamérica, which designates a geographical reference and refers to the states located in the south of the Panama Isthmus. Usually, geographers and historians portray two situations that describe this aspect of geography. The first of these refers directly to the Tehuantepec Isthmus (which connects North and Central America), and the second is a reference to the Panama Isthmus (which connects Central and South America).

When we talk about Latin America, which is a cultural concept, we should first of all include the Mexican state, because the history of the United Mexican States, as well as the cultural aspects that define them, determines the alignment to the various Latin American world. Not only the multiple terms and the perspective of multiculturalism demonstrate the degree of diversity of the American continent, but also the ethnic characteristics represent a strong argument in this direction. Therefore, it is essential to mention the influence that came from another part of the world, which convinces historians, linguists and geographers, to add another term, as eloquent as it is necessary to characterize and understand the diversity of this territory: Afroamérica. When we use this prefix (afro-), we refer to the African heritage on the New World, not only ethnically, but also culturally_for example, the influence on artistic manifestations and religious rituals.

\subsection{Economic, political and social aspects}

Although Latin America is complex and diverse, taking into account several perspectives, this does not necessarily show a world in which only positive aspects predominate. The diversity exemplified in the previous subsection also proves to be doubled by certain visible contrasts and certain negative factors. Regarding these contrasts, an example is given by the states of Uruguay and Paraguay. Unlike Paraguay, Uruguay is considered one of the most developed countries in Latin America, especially economically.

Concerning the economic aspect mentioned above, it is important to point out that another major economic and, therefore, social discrepancy could be highlighted between the situation in Venezuela and Ecuador (a quite underprivileged country in terms of natural resources, but which still exports cocoa beans). A large part of Venezuela's economic progress is due to oil extraction. Of particular relevance that can fuel the arguments of prosperity once recorded in Venezuela is the reference to the remarks of an outstanding literary personality from South America, Isabel Allende, an author of Chilean origin. During the dictatorship launched by the authoritarian leader in Chile, Augusto Pinochet, two members of Allende's family took refuge in Venezuela, then considered prosperous and safe, causing the writer to leave her country, refusing to endure the terrible fear present everywhere, generated by the toxic, dictatorial system, as she herself stated (Allende, 2004, p. 122).

Another important contrast concerns the states of Bolivia and Argentina. If we look at the first of these two countries chosen for the comparison, we can say that Bolivia is constantly showing a high degree of poverty and perhaps we are talking about the most notable degree of social discrepancy on the continent of South America, as opposed to what Argentina represents. It is almost no longer necessary to emphasize the highly developed economy that the state had in the last century. As in the case of Uruguay, Argentina has strengthened one of its most sustainable economic systems in the world. This short parallel is a conclusive and eloquent example, when it comes to reflecting only a small chapter of the huge differences found on

\footnotetext{
${ }^{2}$ It is understood, in this case, the area that centuries ago was conquered by the Kingdom of Portugal—-the current territory of Brazil.
} 
the territories of the same continent, in the same geographical and sociocultural area of the world (Siegel, 2016, p. 113-117) ${ }^{3}$.

But economic disparities are not the only ones affecting the living standards of the Latin American population. The detrimental influence of drugs (especially cocaine) and the plague of populism are also negative factors; that contrast sharply with the cultural variety which represents a great advantage for the southern continent. It is relevant to mention that most of the population in Bolivia (the example mentioned above) is of indigenous origin and we will follow the way in which this topic of Native Americans is reflected in the analyzed novels.

Nowadays, we can say that perhaps the biggest menace that seriously affects this part of the world and that proves to be a generator of social imbalances is the violence: Los indices de homicidio y delito se han incrementado durante 1980 y 1990 en varios paises latinoamericanos ${ }^{4}$ (Aguiar, 2006, p. 115). Crimes, kidnappings, threats, as well as the world of drug traffickers are signs of extreme violence that is manifesting inside the continent and beyond. To clarify, we could add as an example, a contrast between Latin America and Europe. Even if European countries also sum up the most diverse characteristics from various points of view, most of the situations encountered on the Old Continent are not similar to what we find in this part of the New World. Unfortunately, violence has almost become a characteristic cultural imprint.

\section{Concerns in modern literary discourse}

Regarding the Latin American literary works, $\operatorname{Los}_{\operatorname{sordos}}{ }^{5}(2012)$ is the first text analyzed in this study and belongs to Rodrigo Rey Rosa, a Guatemalan writer. The novel focuses on topics such as the social status of an entire social class (represented by the bodyguards, who become always a subject to dangerous tasks, but also to certain compromises) and especially the topic of kidnapping. I would say that the features of a "police" novel merge extremely proportional with the realistic part of the writing, but also with the ambiguity of the situations insinuated by a literary discourse, rather suggestive, than categorical and sententious, used by the author. In addition, the manner in which the novel is conceived, Rey Rosa's writing style increases the impression of ambiguity, creating sequences and fragments that lead us more to the idea of suggestion and open situation, further enhancing the mystery if we think about the deeds of one character or another. We will later observe what epic figures we are referring to.

One of the narrative plans that compose Rodrigo Rey Rosa's novel focuses on the story of a young Guatemalan, Cayetano, who, with the help of his uncle, becomes a bodyguard. Cayetano's permanent mission now is to look after Clara, a woman who seems forced by her father-the most authoritarian figure in the novel—to be watched, against her will. What certainly plays a central role in Rey Rosa's work is the great difference between social classes. We also find in a strong opposition the way the author choose to present the luxurious life of Clara and her relatives, all members of this family being exponents of high society, compared to their bodyguards ${ }^{6}$. On the other hand, the author from Central America emphasizes in his work (using, in fact, numerous terms in Spanish, but which come from the pre-Hispanic Mayan language) another face of society: the indigenous population.

The second narrative plan has in its center another main figure in the novel: the female character Clara, the daughter of a wealthy man, a banker, but also the situations in which readers find her. A very surprising aspect seems to be underlined in a short introductory mention identifying two missing characters, both coming from distinct social classes: Los sordos se inicia con dos desapariciones: la de un niño sordo en un pueblo del interior guatemalteco y la de Clara, hija de un banquero rico y «amable tirano».

\footnotetext{
${ }^{3}$ Siegel argues for social disparities in Central and South America in the geopolitical context: "The environmental governance intersects with economic, and more importantly, social development in Latin America [...] the complex issues of achieving sustainable development in Latin America is tied to the region's position in the global political economy and recent changes in relation to this" (2016, p. 113).

4 "The homicide and crime index increased during the ' 80 s and the '90s in several Latin American states" (our transl.).

${ }^{5}$ The Deaf (our transl.).

${ }^{6}$ Los guardaespaldas.
} 
¿Hay alguna conexión entre ambos hechos? ¿Quépapeljuegan Javier, amante de Clara y abogado de la familia, los guardaespaldas de Clara y de su padre, y los médicos que dirigen un hospital de prácticas sospechosas? ¿Es posible aún alguna forma de amor y de justicia en medio de la violencia?? (Rey Rosa, 2012).

Regarding the ambiguity of the narrative, this could be the strong point of the novel, but, in addition to the idea of mystery, Rodrigo Rey Rosa wants to highlight the serious, disastrous consequences for society that result from violence. The Guatemalan writer undoubtedly refers to the morality that no one is exempt from the imminence of danger and aggression to which everyone is exposed and risks to become a victim (without social status - a deaf and materially disadvantaged child, but also a very rich woman-to matter in any way). Perhaps one of the secondary topics of the book, a theme also fixed by the paratextual element (title) refers to the lack of empathy. On the one hand, we discover, along with the intriguing reading, the fact that the absence of this feeling is manifested towards the natives (on a more general note), and on the other hand, towards the female character Clara, in particular. Her father, extremely authoritarian in his relationship with his family, forces her to be constantly guarded in order to protect her, but without taking into account at all the fact that she wanted freedom, without being pursued everywhere.

In fact, from a linguistic point of view, we can think of an ambivalent perception of the title. The quote mentioned above contains very accurately the essence of the novel. In order to refer to a first interpretation of the textual threshold, in the proper sense, we note that the author chooses two key characters, representatives of different social backgrounds, to be able to mark the obvious lack of empathy for the los indios ${ }^{8}$, reflected in practice which takes place in one of the places intended for carrying out illegal experiments, using children of Mayan origin. In this case, Rodrigo Rey Rosa suggests that in this way the boy who suddenly disappears and who cannot hear, could be exposed (but never explicitly states). Another interpretation of the title, in a figurative sense this time, could refer to the protagonist Clara, a character that others, especially her family (especially her father) do not listen to, do not hear her despair and therefore, do not give her the freedom to live the way she would like.

According to his characteristic style, the author inserts short episodes (but which intentionally arouse the impression of ambiguity and enhance the mystery of events), in which the idea insinuated is that Clara takes refuge, of her own free will, in one of the most mysterious places, described later in the novel. We are talking about a hospital near a lake, where Clara chooses to isolate herself. A part of the action that encourage many interpretations and also builds the plot, could be represented by the attitude of Javier, Clara's lover, who seems to "orchestrate" everything about her "kidnapping". In fact, the two characters are also in a complicity relationship.

In other words, the action is set in a suspicious setting, and the masked violence dominates Rodrigo Rey Rosa's literary universe'. The Guatemalan writer refers, in fact, to a sad reality, reflected in a very special way in his text: some of the hospital institutions built in the middle of the rainforests of Central America serve as a support for illegal, unsafe and terrible experiments, especially on children from Native American families. The location of this place, which becomes for the author, for the narrator and, last but not least, for the reader, an almost "fantastic" ${ }^{10}$, space, on the shores of a lake, seems to really allow the writer to strengthen the structure of the narrative part that focuses on habits and the way of life of the Mayan population. We also notice in this direction the fact that the author insists several times, when it comes to highlighting the contrast between two diametrically opposed worlds. First, Rey Rosa refers to the

\footnotetext{
7 "Los sordos begins with two disappearances: that of a deaf child from a village rooted in Guatemala and that of Clara, the daughter of a rich banker and "kind despot". Is there a connection between the two events? What is the role of Javier, Clara's lover and family lawyer, the bodyguards of Clara and her father, but also the doctors who run a hospital suspected of hosting suspicious practices? Is a form of love and justice still possible in the midst of violence?" (our transl.).

${ }^{8}$ The Native American people.

${ }^{9}$ This dominant theme in the imaginary of the Guatemalan author's work is also found in other of his writings, such as Cárcel de árboles (1992) or El material humano (2009) - The Pelcari Project; Human Matter.

${ }^{10}$ This space, the mysterious hospital, becomes, not only in Los sordos, but also in other specified works, an element that causes a break in the coherence of the realistic part that contributes to the composition of the narrative.
} 
world of ancient traditions and customs, rooted in the indigenous collective imagination, and secondly, the reference is made to the influence of modern civilization and the ability and form of adaptation of this population of pre-Hispanic origin.

As for the power of empathy, the Guatemalan writer does not hesitate to emphasize the scourge of discrimination, more and more present today, at least in his country ${ }^{11}$. The Latin American author identifies from this perspective a circumstance, one of the worst difficulties facing his country and considers that this is the main reason why such medical practices so condemned and controversial exist. He also admits that all this has become an obsession, which has led him to meditate on this issue: No tengo idea de cómo nace ninguna obsesión; de pronto eres victima de una, más bien ${ }^{12}$ (Martinetto, 2012, p. 357).

\section{The confession of a dramatic experience}

Another novel that belongs this time to the Colombian writer Héctor Abad Faciolince and entitled El olvido que seremos ${ }^{13}$ (2006) has as its central topic, the paternal and filial love between a father and his son. Other thematic universes approached by the author in his writing have turned it into a text whose outcome proves to be tragic, because, as in Los sordos, at the center of the action is also violence, deprivation of liberty, fear and the power of sacrifice, in a society severely affected by the adverse context that has taken over some Latin American countries in the last century.

In general terms, the narrator relates, at the first person, in an emotional and personal style, a broad confession about the suffering caused by the loss of the most cherished and loved being by the child Abad: his father. Also, as if this suffering wasn't enough, Abad lost another sister before. Apart from describing an extremely close relationship that the son had with the father and everything that the paternal figure meant to him, we discover in the novel an action that takes place in extremely turbulent times, probably the darkest in the history of independent Colombia, then when the city of Medellín was considered the most risky, violent and dangerous place in the world.

The father's face (ubiquitous in Héctor Abad Faciolince's text) represents the patriarchal society that predominates in Latin America. If we make a brief comparison between this novel and the writing of Rodrigo Rey Rosa, we would say that the relationship that Clara had with her father is very different from the one that existed between Abad and the doctor (according to the language used by the authors, the way to describe these father - son / daughter connections). However, in both cases we can speak of a paternal dominance (reflected in the text, including the lexical level, as we will see in the passage in the next paragraph) which exerts an influence on the infant figure, positive in the text of the Colombian writer or negative, in Rodrigo Rey Rosa’s novel.

Related to the strong affection that the little Abad had for his father, the intensity of the filial feeling reminds of the love and the almost obsessive affection that the narrator-character in Marcel Proust's work, Remembrance of Things Past (an introspective literary journey, guided by which can trigger emotional memory) felt for his mother. In Faciolince's novel there are many remarks about this strong feeling and one of them, extremely eloquent, captures an unusual dialogue in which the young Abad takes part:

$$
\begin{aligned}
& {[\ldots] \text { - Su papá se va a ir para el Infierno. }} \\
& \text { - ¿Por qué? - le pregunté yo. } \\
& \text { - Porque no va a misa. } \\
& \text { - ¿Y yo? } \\
& \text { - Usted va a irse para el Cielo, porque reza todas las noches conmigo. [...] }
\end{aligned}
$$

\footnotetext{
${ }^{11}$ In an interview offered in 2012 to the Spanish daily El País, available online, on the occasion of the publication of his novel, Los sordos, Rodrigo Rey Rosa drew attention to the fact that "in Guatemala there is an 'apartheid' without laws"- "en Guatemala se vive un 'apartheid' sin leyes" (our transl.).

12 "I can't explain how obsessions are born; all of a sudden, you are rather the one who becomes the victim of such feelings" (our transl.).

${ }^{13}$ Oblivion: A Memoir (Abad Faciolince, 2013).
} 
- No voy a volver a rezar.

- ¿Ah, no? - me retó ella.

- No. Yo ya no me quiero ir para el Cielo. A mí no me gusta el Cielo sin mi papá. Prefiero irme para el Infierno con él. ${ }^{14}$

(Abad Faciolince, 2017, p. 8).

If we mentioned the lack of empathy-in Los sordos-, the violence and sacrifices of the characters (especially if we think of the father figure) identified in Abad Faciolince's novel, we could also refer to the documentary called Carta a una sombra ${ }^{15}$. The whole reunited family of the doctor Héctor Abad Gómez relives painful moments, remembering that as long as Héctor was alive, none of them was fully aware of the risk assumed by the person who ended up murdered and whose killers have never been found. However, it would not be superfluous to state that, in the case of family members, we cannot speak of a "lack of empathy", but we could think, rather, of the way in which the doctor wanted to protect his loved ones and, therefore, without their knowledge, he took part in demonstrations for freedom, security, justice and rights. By comparison, the question of the reality reflected by the action of Rodrigo Rey Rosa's novel seems as natural as possible in the case of the Colombian writer: can we still talk the administration of justice when violence is everywhere?

Another aspect that deserves to be addressed and that appears very well represented when it comes to draw a parallel between two novels is related to the role of medicine, which triggered, as we have seen, an obsession in the case of the writer Rodrigo Rey Rosa, but which is exposed in an extremely distinct way both in the work of the Colombian author and in the mentioned documentary, through his father figure or rather through his social status. In Los Sordos, a hospital in the middle of the rainforest where probably illegal, dangerous and unauthorized experiments were carried out is exactly what categorically opposes the ideology based on ethics and goodwill, virtues that characterized the doctor Héctor Abad Gómez.

\section{Conclusions}

It is important to note that the two texts addressed in the present study eloquently reflect, on the one hand, elements that compose the sociocultural variety that defines Central and South America. On the other hand, the two authors capture in their novels a painful reality that characterizes Latin American nations.

We noticed once again, at the time of writing this article, the paradox created by the factors that manage to bring together the civilizations of Latin America, but also by those that separate them and generate deficiencies in asserting identity. The most threatening burden remains the violence, denounced almost every time by representatives of postcolonial literature.

\section{Bibliography}

Abad Faciolince, H. (2013). Oblivion: A Memoir (translated by Anna McLean and Rosalind Harvey), Farrar, Straus and Giroux, New York.

Abad Faciolince, H. (2017). El olvido que seremos, Alfaguara, Madrid.

Aguiar, J.C.G. (2006). Las politicas de seguridad pública en América Latina: policía, violencia y narcotráfico en México, in "European Review of Latin American and Caribbean Studies", 81, p. 115-121, Crossref.

Allende, I. (2004). My Invented Country, A Memoir (translated by Margaret Sayers Peden), Harper Perennial, New York.

Barceló, R., Sánchez, M.J. \& Portal, M.A. (coord.) (2013). Diversidad étnica y conflicto en América Latina, II. El indio como metáfora en la identidad nacional, Plaza y Valdés Editores, Madrid.

\footnotetext{
${ }^{14}[\ldots]$ - Your father will go to hell./ - Why? - I asked./ - Because he doesn't attend the service./ - And me?/ - You will go with me to Heaven, because you pray every night with me. [...]/ - I won't say any more prayers./ - Oh, right? - She challenges me./ - No. I don't want to go to Heaven anymore. Heaven would not delight me without my father. I'd better go to hell with him" (our transl.).

${ }^{15}$ Letter to a shadow-our transl., available online.
} 
De la Torre, C. (2013). In the Name of the People: Democratization, Popular Organizations, and Populism in Venezuela, Bolivia, and Ecuador, in "European Review of Latin American and Caribbean Studies", 95, p. 27-48, Crossref.

Gutiérrez de MacGregor, M.T. (2009). La Geografía en América Latina: visión por países, in "Investigaciones geográficas”, 69, [online].

Klein, M. (2003). The Human Rights Violations of the Pinochet Regime and Their Legacy, in "European Review of Latin American and Caribbean Studies", 74, p. 107-114, Crossref.

Kruijt, D. (2003). Post-War Central America, in “European Review of Latin American and Caribbean Studies”, 75, p. 119-126, Crossref.

Manzoni, C., (ed.) (2005). Violencia y silencio: literatura latinoamerica contemporánea, Corregidor, Buenos Aires.

Martinetto, V. (2012). Breve entrevista a Rodrigo Rey Rosa, in "Revista de literatura hispánica", 1 (75), p. 357.

Rey Rosa, R. (2012). Los sordos, Alfaguara, Madrid.

Siegel, K.M. (2016). Environment, Politics and Governance in Latin America, in "European Review of Latin American and Caribbean Studies", 102, p. 109-117, Crossref.

Suselbeck, K. (2008). Lengua, nación e identidad: la regulación del plurilingüismo en España y América Latina, Iberoamericana Editorial Vervuert, Madrid.

Vargas Llosa, M. (2009). Sueño y realidad de América Latina, Fondo Editorial de la Pontificia Universidad Católica del Perú, Lima.

Zanatta, L. (2012). Historia de América Latina. De la colonia al siglo XXI (translated by Alfredo Grieco y Bavio, Guillermo David), Siglo Veintiuno Editores, Buenos Aires. 